\title{
PERGESERAN DAN KONFIGURASI POLITIK HASIL PILEG 2019: KAJIAN DAN ANALISIS TERHADAP DINAMIKA POLITIK DI SULAWESI SELATAN
}

\author{
Syarifuddin Jurdi \\ Komisioner KPU Provinsi Sulawesi Selatan dan Dosen UIN Alauddin Makassar \\ Email:sjurdi06@gmail.com
}

\begin{abstract}
Abstrak
Pemilihan umum (Pemilu) merupakan sarana kedaulatan rakyat, melalui Pemilu akan diseleksi elite pemimpin melalui pemilihan yang demokratis. Pemilu Serentak 2019 merupakan Pemilu pertama yang menyatukan pemilihan presiden-wakil presiden dengan pemilihan legislatif, hasil Pemilu menunjukkan adanya pergeseran dan pertukaran posisi antar elite berkuasa. Berdasarkan hasil Pemilu 2019 di Sulawesi Selatan terjadi pergeseran posisi elite, dari total 85 anggota DPRD Provinsi Sulawesi Selatan, 59 orang merupakan pendatang baru (pertama terpilih sebagai anggota DPRD Provinsi), hanya 26 orang incumbent yang masih terpilih. Pergeseran posisi ini disebabkan oleh meningkatnya kesadaran politik warga, juga dipengaruhi oleh adanya praktek klientalisme dan patronase. Sejumlah elite terpilih merupakan calon yang tidak terlalu kuat mengakar, juga bukan elite yang menonjol dalam masyarakat, namun faktor " $X$ ” yang mengantarkan sejumlah calon pada DPRd provinsi Sulawesi Selatan. Di antara elite terpilih terdapat sejumlah nama yang merupakan keluarga atau kerabat elite berkuasa, misalnya putra Bupati Bone terpilih sebagai anggota DPRD provinsi, putra anggota DPRD RI dari PPP juga diduga ia terpilih, karena pengaruh ayahnya.
\end{abstract}

Kata Kunci:

Pergeseran, Konfigurasi, Hasil Pemilu Legislatf 2019, Penyelenggara Pemilu

\begin{abstract}
Elections are a means of popular sovereignty, through the Election the elite leaders will be selected through democratic elections. 2019 Simultaneous Election is the first election that unites the president-vice presidential election with the legislative election, the election results show a friction and exchange of positions between the ruling elite. Based on the results of the 2019 elections in South Sulawesi, there was a shift in the position of the elite, out of a total of 85 members of the South Sulawesi Provincial DPRD, 59 people were newcomers (first elected as members of the Provincial DPRD), only 26 incumbents were still elected. This shift in position was caused by increased political awareness of citizens, also influenced by the practice of clientelism and patronage. A number of elected elites were candidates who were not too firmly rooted, nor were elites who stand out in the community, but the " $X$ " factor that lead a number of candidates to the DPRD of South Sulawesi province. Among the elected elites there were a number of names that were family or relatives of the ruling elite, for example the
\end{abstract}


son of the Regent of Bone was elected as a member of the provincial DPRD, the son of a DPRD RI member from PPP was also thought to have been elected, because of his father's influence.

\section{Keywords:}

Friction, Configuration, 2019 Legislative Election Results, Election Organizer

\section{Pendahuluan}

Pemilihan Umum (Pemilu) Serentak tahun 2019 merupakan pesta demokrasi yang cukup panjang, masa kampanye dimulai sejak tahun 2018 dan berlangsung hingga masa tenang tiga hari sebelum hari pemungutan suara tanggal 17 April 2019. Produk Pemilu Serentak 2019 adalah elite politik yang terpilih, baik presiden dan wakil presiden, Dewan Perwakilan Daerah (DPD) dan Dewan Perwakilan Rakyat (DPR), DPRD Provinsi dan DPRD Kabupaten/Kota. Untuk menghasilkan kepemimpinan politik melalui Pemilu serentak, penyelenggaraan Pemilu yakni Komisi Pemilihan Umum (KPU) dan Badan Pengawas Pemilu (Bawaslu) bekerja maksimal untuk memastikan bahwa seluruh proses Pemilu berjalan sesuai dengan regulasi dan standar norma yang berlaku.

Penyelenggara Pemilu pasca Orde Baru sebagaimana yang tertuang dalam UUD 1945 hasil amandemen tahun 2000 pasal 22E. Amandemen ini dilakukan setelah Pemilu 1999, istilah penyelenggara pada Pemilu yakni oleh KPU, keanggotaannya terdiri dari wakil pemerintah dan wakil partai politik peserta Pemilu. Dasar hukum yang menjadi acuan penyelenggaraan Pemilu 1999 yakni UU Nomor 3 Tahun 1999 Tentang Pemilihan Umum, dalam UU ini disebutkan struktur kelembagaan KPU tidak lagi didominasi oleh pemerintah, namun juga menyertakan wakil dari setiap partai politik peserta Pemilu. Kedua unsur ini, meskipun jumlahnya berbeda, namun hak suaranya ditentukan berimbang. ${ }^{1}$ Struktur kelembagaan KPU ini merupakan produk reformasi yang bersifat awal, karena komposisi penyelenggara Pemilu merupakan kombinasi pemerintah dan peserta Pemilu, belum dikenal adanya pengawas atau badan pengawas Pemilu.

1 Andi A. Mallarangeng, "Peraturan Perundang-Undangan Pemilu 1999 dan Agenda Perubahan", dalam Juri Ardiantoro (ed.), Transisi Demokrasi: Evaluasi Kritis Penyelenggaraan Pemilu 1999 (Jakarta: KIPP Jakarta, 1999), h. 75-84; A. Malik Haramain dan MF. Nurhuda, Mengawal Transisi: Refleksi atas Pemantanan Pemilu '99 (Jakarta: JAMPPI-UNDP, 2000), h. 115-120. Selain unsur pemerintah dan partai politik, sebenarnya ada usulan dalam draft RUU agar memasukkan unsur masyarakat sipil. Namun usulan ini tidak mendapat dukungan mayoritas di parlemen. 
Meskipun demikian, penyelenggara Pemilu sudah mengalami kemajuan, karena kombinasi partai politik dan pemerintah, namun implikasi dari model penyelenggara Pemilu seperti ini menimbulkan konflik internal, pengambilan keputusannya pun berlarut-larut. Keadaan inilah yang kemudian direproduksi untuk mencapai format kelembagaan yang lebih baik dan ideal, hal itu tercantum dalam UU Nomor 12 Tahun 2003, yakni UU yang digunakan sebagai dasar penyelenggaraan Pemilu 2004. Pada BAB IV yang mengatur tentang Penyelenggara Pemilihan Umum, ditegaskan bahwa Pemilu diselenggarakan oleh KPU yang bersifat nasional, tetap, dan mandiri (Pasal 15 ayat 1). Namun dalam UU ini tidak didapatkan uraian terperinci tentang apa yang dimaksud dengan nasional, tetap, dan mandiri.

Kelembagaan penyelenggara Pemilu menjadi faktor krusial dalam proses Pemilu, penjelasan terkait kelembagaan penyelenggara Pemilu sebagai pengetahuan dan pemahamn bahwa produk Pemilu yang kredibel akan ditentukan oleh penyelenggara yang independen. Ketika keaggotaan KPU yang berasal dari wakil-wakil partai politik, maka mereka lebih terlihat memperjuangkan kepentingan pribadi dan partainya masingmasing. Akibatnya, pengambilan keputusan di KPU berlangsung bertele-tele. Yang puncaknya berujung pada kegagalan KPU menjalankan kewenangannya untuk menetapkan hasil Pemilu 1999, dan akhirnya kewenangan itu diserahkan oleh KPU kepada Presiden Habibie. ${ }^{2}$ Transformasi kelembagaan KPU terus berlanjut dengan adanya perbaikan regulasi yang memungkinkan KPU menjadi Lembaga yang mandiri, otonom dan bersifat tetap dan nasional. Melalui proses politik yang mempertimbangkan posisi dan peran KPU, maka Pemerintah dan DPR menyepakati untuk merumuskan ulang desain kelembagaan KPU melalui revisi atas UU Nomor 3 Tahun 1999. Dalam Pasal 8 ayat (2) UU Nomor 4 Tahun 2000 Tentang Perubahan atas UU Nomor 3 Tahun 1999 disepakati sebuah rumusan bahwa: "Penyelenggaraan Pemilihan Umum dilaksanakan oleh Komisi Pemilihan Umum yang independen dan nonpartisan".3

\footnotetext{
2 Mulyana W. Kusuma, "Pelaksanaan Pemilihan Umum Tahun 1999,” dalam Juri Ardiantoro (ed.), Transisi Demokrasi: Evaluasi Kritis Penyelenggaraan Pemilu 1999 (Jakarta: KIPP Jakarta, 1999), h. 127-148.

${ }^{3}$ Ni'matul Huda dan M. Imam Nasef, Penataan Demokrasi \& Pemilu di Indonesia Pasca Reformasi (Jakarta: Fajar Interpratama Mandiri, 2017), h. 67. Dalam Penjelasan pasal ini diterangkan bahwa, "Komisi Pemilihan Umum yang independen dan non-partisan artinya Komisi Pemilihan Umum yang bebas, mandiri, dan tidak berada di bawah pengaruh serta tidak berpihak kepada seseorang, kelompok tertentu, partai politik, dan/atau Pemerintah."
} 
Pemilu Serentak 2019 diselenggarakan oleh suatu lembaga penyelenggara Pemilu yang bersifat nasional, tetap dan mandiri sebagaimana bunyi amandemen ketiga yang disepakati pada 9 November 2001, Pasal 22 E ayat (5), yakni, "Pemilihan Umum diselenggarakan oleh suatu komisi pemilihan umum yang bersifat nasional, tetap, dan mandiri." Oleh sebab itu, dapat dipahami bahwa penyelenggaraan Pemilu sejak tahun 2004, 2009, 2014 dan Pemilu Serentak 2019 diselenggarakan oleh suatu komisi yang bersifat mandiri dan nasional. Sebagai institusi yang menjamin hak-hak konstitusional warga negara tersalurkan dengan baik, KPU bekerja profesional dan independen tanpa campur tangan dari pihak manapun.

Dalam melakukan analisis terhadap dinamika pergeseran dan konfigurasi elite politik pasca Pemilu Serentak 2019 memerlukan suatu cara atau metode. Dalam hal ini, metode yang digunakan dalam penulisan ini adalah metode induktif-analitis. Dalam metode ini kesimpulan-kesimpulan umum yang diperoleh didasarkan pada proses pemikiran setelah mempelajari pristiwa-peristiwa khusus atau peristiwa-peristiwa yang konkret. ${ }^{4}$ Metode deskriptif-analitis ini sengaja dirancang untuk mengumpulkan informasi tentang keadaan-keadaan yang nyata sekarang. Disebut deskriptif - analitik karena memberikan penggambaran tentang kenyataan-kenyataan yang bersifat partinen (sungguh-sungguh ada). Tujuan utama memakai metode ini adalah untuk menggambar kan sifat suatu keadaan yang sementara berjalan pada saat penelitian dilakukan dan memeriksa sebab-sebab dari suatu gejala tertentu. ${ }^{5}$ Data yang digunakan dalam penelitian lebih mengandalkan data sekunder dengan mengumpulkan data-data yang merupakan hasil dari proses Pemilu 2019 dan kecenderungan komposisi keterwakilan politik di parlemen.

Analisis terhadap informasi yang diperoleh menggunakan tipe tindakan sosial Max Weber yakni tindakan rasionalitas instrumental (zwekrationalitat) dan rasionalitas nilai (wertrationalitat). Zweckrationalitat merupakan tipe rasionalitas yang mencakup pemilihan dan pertimbangan sadar yang berkaitan dengan tujuan dari suatu tindakan. Tipe ini secara sadar mempertimbangan berbagai tindakan atau cara-cara yang dilakukan oleh elite-elite politik dan dihubungkan dengan usaha untuk mencapai tujuan.

\footnotetext{
${ }^{4}$ F. Isjwara, Pengantar Ilmu Politik (Jakarta : Bina Cipta, 1992), h. 65.

${ }^{5}$ Consuelo G. Sevilla, et.al, Pengantar Metode Penelitian, Terjemahan Alimuddin Tuwu (Jakarta: UI Press, 1993), h. 71.
} 
Pilihan yang diambil akan mempertimbangkan berbagai implikasinya, seperti manfaat dan juga resiko dari pilihan yang ditempuh. Sementara wertrationalitat adalah tujuan dari suatu tindakan. ${ }^{6}$ Tujuan itu telah ada dan telah digariskan oleh partai politik melalui musyawarah untuk melahirkan kesepakatan bersama, dan itulah yang dianggap sebagai nilai tertinggi. Individu-individu tunduk dan taat pada keputusan itu, karena itu merupakan nilai-nilai yang dianggap benar dan berusaha diwujudkan secara bersama.

\section{Pemaknaan terhadap Elite Politik}

Dalam kehidupan umat manusia selalu ada varian hidup yang menarik perhatian masyarakat, di antara varian itu adalah kehidupan kelas atas dan kaum elite dalam masyarakat. Studi dan kajian mengenai elite politik telah menghasilkan begitu banyak karya, baik studi yang membahas elite secara teoritik maupun praktek politik yang dilakukan oleh kaum elite dalam masyarakat. Eksistensi elite politik tidaklah bersifat tunggal dan berdiri terpisah dengan kehidupan masyarakat, melainkan memiliki keterkaitan dengan konstruksi sosial budaya yang dapat membedakan antara satu komunitas dengan komunitas lainnya. ${ }^{7}$

Secara sederhana elite dapat diartikan sebagai anggota masyarakat yang paling berbakat (misalnya elite pendidikan, elite agama, elite organisasi), siapa saja yang memiliki potensi dan bakat yang tinggi dalam suatu komunitas, terlepas asal usulnya, maka yang bersangkutan dapat dimasukkan dalam kategori elite. Dalam perspektif sosiologi politik, elite itu lebih banyak ditujukan kepada elite politik (political elite). Menurut David Jarry dan Julia Jarry bahwa asumsi teori elite yang membagi antara kaum elite dan rakyat jelata, merupakan ciri yang tidak terelakkan dalam masyarakat modern yang kompleks dimanapun juga, menurutnya asumsi yang mengatakan bahwa rakyat secara keseluruhan yang menjalankan pemerintahan adalah sesuatu yang keliru. ${ }^{8}$

\footnotetext{
${ }^{6}$ F Budi Hardiman, Kritik Ideologi: Pertautang Pengetabuan dan Kepentingan (Yogyakarta, Kanisius, 1993), h. 33.

7 Elite politik terkoneksi dengan kehidupan politik kekuasaan, terkoneksi dengan komunitas kebudayaan, terkoneksi dengan agama, terkoneksi dengan kelompok intelektual dan sebagainya. Karena itu pembicaraan mengenai komunitas elit tentu mengundang perhatian sekaligus perdebatan yang menarik dari berbagai kalangan yang ada dalam masyarakat terutama dari kalangan ilmuwan sosial yang selama ini memang lebih memfokuskan perhatian pada masalah sosial politik dan kekuasaan. Perhatian dan perdebatan mengenai elit justru akan semakin membantu dalam memperluas dan memperkaya teori mengenai elit, lihat misalnya Syarifuddin Jurdi, Elite Muhammadiyah dan Kekuasaan Politike (Yogyakarta: Gadjah Mada University Press, 2004)

${ }^{8}$ David Jarry dan Julia Jarry, Collin Dictionary of Sociologi (Glasgow :Harper Collins Publishers, 1991), h. 188.
} 
Hal ini justru menggambarkan bagaimana posisi elite itu ditempatkan pada wilayah yang sungguh bermakna politik, walaupun diakui munculnya elite-elite yang terspesialisasi dalam berbagai bidang kehidupan.

Para ilmuwan sosial telah memelopori dan mengetengahkan teori tentang elite terutama dihubungkan dengan kehidupan politik kenegaraan atau berkaitan langsung dengan posisi sosial seseorang baik dalam lingkup keagamaan atau profesi lainnya. Sementara istilah elite itu sendiri mulai digunakan pada abad ketujuh belas untuk menyebut barang dagangan yang mempunyai keutamaan khusus (berkualitas tinggi), lalu kemudian digunakan untuk menyebut kelompok-kelompok sosial dalam masyarakat yang juga didasarkan pada posisi sosial yang tinggi, seperti kesatuan militer yang utama dan kalangan bangsawan". Istilah elite berasal dari bahasa latin yaitu "eligere" atau dalam bahasa inggrisnya "elite” yang berarti memilih. Dalam pemakaian biasa kata tersebut berarti "bagian yang menjadi pilihan" suatu bangsa, budaya, kelompok usia dan orang-orang yang menduduki posisi sosial yang lebih tinggi. ${ }^{10}$ Dengan perkataan lain, yang disebut elite adalah sekelompok kecil orang dalam masyarakat yang memegang posisi dan peranan penting. Menurut Harold Laswell, elite merupakan segolongan kecil yang memperoleh sebagian besar dari nilai apa saja, elite itu menunjuk kepada mereka yang berpengaruh. ${ }^{11}$

Ahli lain memberi pemaknaan yang lebih tegas lagi mengenai elite, Sosiolog C. Wright Mills mengemukakan bahwa elite adalah mereka yang menduduki posisi atas dalam institusi ekonomi, militer dan politik,.... membentuk kurang lebih elite kekusaan yang terintegrasi dan terpadu yang keputusan-keputusan pentingnya menentukan struktur dasar dan arah masyarakat, ${ }^{12}$ lebih lanjut Mills ungkapkan bahwa elite kekuasaan bukanlah suatu klik yang tertutup atau statis dengan seperangkat kebijaksanaan yang benar-benar terpadu. ${ }^{13}$ Dalam arti yang lebih tegas, Jarry dan Jarry menyebut bahwa munculnya demokrasi dalam masyarakat modern bukannya memberi

${ }^{9}$ Konsep elite pada awalnya dipergunakan untuk menunjukkan suatu barang yang memiliki kualitas tinggi . Penjelasan secara terinci mengenai masalah elite serta hubungannya dengan struktur sosial, lihat Tom B. Bottomore, "Kelas elite dan Masyarakat" dalam Sartono Kartodirdjo (eds.) Kepemimpinan dalam Dimensi Sosial, (Jakarta: LP3ES, 1990), h. 24

10 Suzanne Keller, Penguasa dan Kelompok Elit: Peranan Elit dalam Masyarakat Modern, terjemahan Zahara D Noer (Jakarta: Rajawali Press, 1995), h. 3.

${ }^{11}$ Sunarlan, "Gerakan Reformasi Politik". Tesis. (Yogyakarta: Program Politik Fisipol UGM, 2000).

12 Doyle P. Johnson, Teori Sosiologi Klasike \& Modern, Jilid II (Jakarta: Gramedia Pustaka Utama, 1994), h. $174-175$.

${ }^{13}$ Ibid. h. 178. 
kekuasaan pada rakyat melainkan meletakkan dasar baru bagi keanggotaan kelompok elite. ${ }^{14}$ Demokrasi yang menempatkan pemilihan umum (Pemilu) sebagai satu mekanisme politik untuk melakukan sirkulasi kekuasaan pada prinsipnya menurut Jarry adalah suatu cara untuk terus-menerus mempertahankan posisi elite dan melanggengkan status quo mereka, demokrasi dalam hal ini merupakan sarana kalangan elite untuk berebut dan mempertahankan kekuasaannya.

Elite merupakan satu lingkaran yang secara kontinyu bergerak dan saling berkoneksi, elite politik tetaplah memerlukan kelompok sosial lain untuk menggerakkan kekuasaannya, namun demikian, elite merupakan kelompok masyarakat yang menempati kelas sosial atas, untuk terus bertahan pada posisi elite, mereka memerlukan partisipasi dan dukungan massa. Dalam konteks ini, elite merupakan kelompok individu yang memainkan dua peran sekaligus yakni menentukan jalankan pemerintahan /kekuasaan dan mendistribusikan kebaikan kepada rakyat, disinilah apa yang disebut oleh Samuel Hungtington dan Nelson bahwa ada sikap "elitisme” yang bijak dikalangan kelompok yang berkuasa. ${ }^{15}$ Sikap elite politik terhadap partisipasi politik mungkin merupakan faktor tunggal yang paling efektif dalam mempengaruhi sifat partisipasi politik di masyarakat. ${ }^{16}$

Elite politik merupakan kelompok masyarakat yang menempati posisi tersendiri dalam struktur sosial, sehingga Vilfredo Pareto membagi elite menjadi dua yaitu pertama, elite yang memerintah, yakni elite yang terlibat langsung atau tidak langsung dalam kekuasaan; kedua, elite yang tidak memerintah, yakni merupakan sisa yang besar dari seluruh elite. ${ }^{17}$ Dalam sejumlah kajian mengenai elite, focus perhatian diletakkan pada elite yang memerintah, karena merekalah yang menentukan arah kehidupan sosial politik warga dan menentukan jalannya pemerintahan. Elite berkuasa pada tahun 2019 mengalami sirkulasi, khususnya elite politik di lembaga-lembaga legislatif.

Pergeseran dan perubahan struktur kekuasaan elite tampak melalui hasil Pemilu 2019, pergeseran posisi elite sebagai konsekuensi dari proses interaksi antara berbagai kepentingan yang bertarung dalam Pemilu Serentak 2019. Elite baru yang terpilih

\footnotetext{
${ }^{14}$ David Jarry dan Julia Jarry, Op. Cit. h. 189.

15 Samuel P. Huntington dan Joan Nelson, No Easy Choice Political Partisipation in Developing Countri terjermahan (Jakarta: Rineka Cipta, 1994), h. 37.

${ }^{16}$ Ibid. h. 39.

17 Robert D. Putnam, "Studi Perbandingan Elit Politik" dalam Mohtar Mas'oed dan Colin Mac Andrews, Perbandingan Sistem Politike (Yogyakarta: Gadjah Mada Universty Press, 2000, cet. kelimabelas), h. 78.
} 
bukanlah elite yang sama sekali aktor yang baru muncul, melainkan aktor lama yang sudah dikenal luas oleh warga dan berhasil melakukan penetrasi masuk dalam struktur kekuasaan legislatif melalui Pemilu, proses yang terjadi lebih bersifat pertukaran posisi elite, dari elite yang tidak berkuasa ke posisi elite berkuasa, dari peran-peran sosial kemanusiaan ke peran politik kenegaraan.

\section{Elite Politik dan Pergeseran Posisi}

Dengan menggunakan perspektif elite, pemahaman mengenai pergeseran posisi dan peran elite politik pasca Pemilu Serentak 2019 merupakan keharusan sejarah, mengingat posisi elite yang strategis menentukan masa depan masyarakatnya. Masyarakat Indonesia dan khususnya Sulawesi Selatan memiliki jumlah yang mencapai jutaan, sementara mereka yang termasuk dalam kategori elite politik jumlahnya sangat terbatas. Itulah yang disebut oleh Mills sebagai elite yang mampu memainkan peran strategis pada berbagai bidang kehidupan termasuk berpindah posisi menjadi elite politik. Keberhasilan elite politik mencapai posisi puncak tidak bisa dilepaskan dari kemampuan intelektual dan penyebaran kekuatan ke berbagai komunitas yang berhasil dimobilisasi untuk memberi mandat kuasa. ${ }^{18}$ Elite politik memiliki posisi yang jauh lebih strategis menentukan masa depan bangsa dan negara bila dibandingkan dengan kelompok elite yang lainnya.

Pada Pemilu Legislatif serentak tahun 2019 terjadi sejumlah fenomena unik dan menarik berkenaan dengan pergeseran kekuasaan elite politik. Pergeseran politik yang terjadi memiliki makna yang paradoks antara isu-isu teologi keagamaan, isu-isu ekonomi, integrasi sosial, isu-isu kemanusiaan lainnya dengan kecendrungan keterpilihan wakil rakyat pada Pemilu Serentak 2019. Gagasan politik yang muncul pada Pemilu Serentak 2019 relatif tidak hadir secara massif di ruang politik, justru isu dan wacana politik Pilpres jauh lebih kuat dan dominan. Keterpilihan partai politik pada Pemilu legislatif merupakan hasil pertemuan antara berbagai aspek termasuk koneksi antar berbagai wacana politik kebangsaan yang terbangun dalam periode kampanye

18 Lihat sejumlah karya terkait, Samuel P. Huntington dan Joan Nelson, No Easy Choice Political Partisipation In Developing Countri; Suzanne Keller, Penguasa dan Kelompok Elit; Sartono Kartodirdjo (eds.) Kepemimpinan dalam Dimensi Sosial; Syarifuddin Jurdi, Elite Mubammadiyah dan Kekuasaan Politik. 
Pemilu, penetrasi elite partai politik sebagian efektif mempengaruhi keterikatan warga dengan partai politik dan sang kandidat. ${ }^{19}$

Sejak Orde Baru hingga Pemilu 2014, Partai Golkar merupakan partai politik yang cukup kuat mengakar dalam masyarakat Sulawesi Selatan, meski Golkar diidentikkan dengan partai Orde Baru dan merupakan partai yang paling bertanggung jawab atas kemerosotan bangsa, tidak berarti partai ini mengalami pemudaran pengaruh, bahkan pasca Orde Baru menunjukkan bahwa partai ini masih cukup kuat dan dominan. Pada tahun 1998-1999 banyak partai politik baru yang berdiri, partai yang lahir dari reformasi politik 1998, menawarkan berbagai agenda perubahan dan perbaikan kehidupan bangsa dan negara, banyak partai juga banyak gagasan baru untuk Indonesia masa depan, namun dalam kenyataannya, partai-partai tersebut gagal memperoleh dukungan luas dari masyarakat, bahkan ada yang harus bubar sebagai konsekuensi dari pengaturan batas minimal perolehan dukungan masyarakat (parlementary threshold). ${ }^{20}$

Perubahan politik mengikutsertakan adanya perubahan pada struktur kekuasaan, Pemilu 2004 misalnya memberi kejutan baru, tidak saja partai-partai lama gagal meningkatkan dukungan publik, juga gagal mengantarkan para pemimpin mereka menjadi pemimpin bangsa, justru yang tampil sebagai pemimpin bangsa berasal dari partai yang baru pertama mengikuti Pemilu 2004 yakni Susilo Bambang Yudhoyono (SBY) dengan partai barunya yakni Partai Demokrat. Pertukaran elite politik merupakan hal yang biasa pasca reformasi 1998, munculnya partai politik baru dan memudarnya partai politik lama sebagai bagian dari proses transisi politik, partai baru yang lahir pasca reformasi yang eksis hingga kini yakni Partai Demokrat, PKS, Partai Gerindra dan Partai Nasdem, sementara Partai Hanura gagal mempertahankan posisinya sebagai partai yang lolos parlementary threshold. ${ }^{21}$

\footnotetext{
${ }^{19}$ Beberapa elite baru yang terpilih dalam Pemilu legislative 2019 merupakan aktor politik yang belum memiliki pengaruh kuat di masyarakat, namun hasil penetrasi langsung ke komunitas menyebabkan yang bersangkutan terpilih, tentu dengan gagasan politiknya.

${ }^{20}$ Sejak Pemilu 2004, partai politik yang tidak memperoleh dukungan Parlementary threshold 2 persen, kemudian prosentase tersebut naik menjadi 3 persen dan terakhir menjadi 4 persen, maka partai politik tersebut tidak berhak menempatkan wakilnya di DPR RI.

21 Partai politik yang bertahan ini merupakan partai yang lahir dari konflik internal Golkar, Partai Hanura lahir pasca Wiranto gagal menjadi presiden pasca Pilpres 2004, Wiranto Calon Prrsiden hasil konvensi Partai Golkar, Partai Gerindra dimotori oleh Prabowo yang kemudian pada Pemilu 2009 maju sebagai calon Wakil Presiden berpasangan dengan Megawati Soekarno Putri, terakhir Partai Nasdem yang lahir dari perebutan ketua umum Golkar di Riau yang dimenangkan oleh Abu Rizal Bakri, sementara Surya Paloh yang gagal menginisiasi lahirnya satu gerakan baru yang bermetamorfosis menjadi partai politik. Partai Nasdem
} 
Konfigurasi elite politik pasca Pemilu 2014 menunjukkan adanya pergeseran elite, hasil Pemilu menunjukkan adanya upaya untuk "memotong" dominasi partai besar dan menggeser menjadi satu kekuatan politik yang berimbang, Partai Nasdem merupakan fenomena unik di Sulawesi Selatan, karena berhasil tamp;il sebagai kekuatan politik “besar", pada Pemilu 2014 berhasil menempatkan wakilnya pada posisi pimpinan DPRD Provinsi, suatu lompatan yang sangat signifikan melampaui perolehan suara dan kursi partai-partai besar seperti PDI Perjuangan, PKB, PPP, PKS dan partai lainnya. Partai baru mengorbitkan elite baru pada posisi strategis di parlemen, ini menggeser kekuatan lama.

Peningkatan dukungan terhadap partai baru sebagai bagian dari "protes" warga terhadap kinerja elite politik yang telah berkuasa, bahkan pergeseran yang menarik justru terjadi pasca Pemilu 2019. Pada level provinsi, partai Golkar sebagai partai "tradisional"nya warga Bugis-Makassar hanya mampu menang tipis dari partai-partai lainnya yang lolos parlementary threshold empat persen, meski untuk keterwakilan tingkat provinsi tidak ditentukan oleh ambang batas tersebut. Perolehan suara dan konversi kursi partai politik tingkat provinsi Sulawesi Selatan hasil Pemilu Serentak 2019 menunjukkan adanya pergeseran kesetiaan rakyat terhadap elite politik dan partai politik. Partai-partai politik yang selalu menduduki posisi penting dalam tiga kali Pemilu terakhir $(2004,2009,2014)$ mengalami kemunduran perolehan suaranya.

Bangkitnya partai politik baru hasil Pemilu Serentak 2019 merupakan fenomena menyeluruh dalam perebutan kursi parlemen, sebelum Pemilu diselenggarakan, banyak kalangan menduga ada partai politik tertentu yang bakal hilang di Senayan, sementara partai-partai yang baru mengikuti Pemilu 2019 diprediksi oleh berbagai Lembaga Survei bisa menembus batas 4 persen. Fenomena menarik ini dapat dijelaskan dengan melihat kecendrungan perilaku politik warga, hal itu dapat digambarkan dalam beberapa hal; pertama, rakyat tidak lagi bergantung pada partai politik tertentu, melainkan orientasi dan pilihan kepada figur atau aktor politik menjadi umum dilakukan. Untuk menganalisa kecendrungan pergeseran tersebut dapat dilihat dari kecendrungan pemihakan elite-elite politik dan klan yang berkuasa. Sebagai kasus, migrasinya klan Yasin Limpo dari Partai Golkar ke Partai Nasdem yang diikuti oleh sejumlah gerbonnya

pertama mengikuti Pemilu 2014 dan berhasil lolos parlementary threshold dan kini partai tersebut terus berkembang di berbagai daerah. 
menjadi salah satu indikasi kuat bahwa institusi partai tidaklah menjadi faktor penentu bagi rakyat dalam menentukan calon legislatif, tetapi pemihakan pada aktor, meskipun Syahrul Yasin Limpo sendiri gagal menjadi anggota DPR RI, karena hanya mampu memperoleh suara terbanyak keempat pada Daerah Pemilihan Sulawesi Selatan 2. Beberapa kepala daerah yang sedang berkuasa ikut menentukan keterpilihan caleg, sebagai dari caleg terpilih merupakan kerabat pejabat. ${ }^{22}$

Kedua, regenerasi politik menjadi faktor penentu dalam keterpilihan partai politik. Partai-partai yang mengandalkan klan politik mengalami dilema dalam proses sosialisasi politiknya, meskipun pengaruh elite berkuasa dan modal yang dimiliki masih menjadi penentu dalam keterpilihan caleg. Secara umum, partai politik kurang memperhatikan kaderisasi untuk proses pencalonan, sebagian partai memilih strategi instan dalam proses pencalonan, misalnya mengusung putra, putri atau kerabat pejabat sebagai caleg, juga mengusung tokoh yang populer agar dapat meraup suara yang besar. Pimpinan partai yang sedang berkuasa dengan maksimal mendorong agar kerabatnya dapat terpilih sebagai anggota legislatif, dalam hal ini kasus keterpilihan anaknya Ketua DPP PPP Amir Uskara yakni Imam Fauzan AU sebagai anggota DPRD Provinsi Sulawesi Selatan, tentu keterpilihan ini memperoleh dukungan dari struktur partai, mengingat Imam Fauzan merupakan pendatang baru dalam percaturan politik di Sulawesi Selatan.

Ketiga, preferensi politik rakyat tidak lagi pada konteks pengaruh aktor semata atau ketenaran, melainkan pada hubungan yang intens antara rakyat dengan sang calon. Sebagai kasus, caleg Syahrul Yasin Limpo yang merupakan Gubernur Sulawesi Selatan periode 2008-2013 dan 2013-2018, orang yang paling berpengaruh dan paling popular di Sulawesi Selatan selama sepuluh tahun gagal terpilih sebagai anggota DPR RI pada Dapil Sulawesi Selatan 2, kegagalan ini sebagai indikator bahwa ketenaran bukan penentu, melainkan hubungan yang akrab antara caleg dengan rakyat. Sementara ada caleg yang masih cukup belia dari PKS, bukan anak pejabat, lahir dari kalangan rakyat biasa, namun dalam tempo yang lama membangun hubungan baik dengan warga

22 Caleg Partai Nasdem terpilih untuk DPR RI Dapil Sulawesi Selatan 2 merupakan istri dari Bupati Barru, sejumlah istri Bupati dan Walikota maju sebagai caleg seperti istri Bupati Wajo, Walikota Parepare, Walikota Makassar. 
melalui berbagai program pemberdayaan masyarakat, yang bersangkutan bisa terpilih sebagai anggota DPRD Provinsi Sulawesi Selatan pada Dapil 7 Kabupaten Bone.

\section{Dari Elite Berkuasa ke Aktor Baru}

Pemilu Serentak 2019 menjadi arena pertarungan bagi elite politik, elite-elite lama bertarung menghadapi pendatang baru memperebutkan dukungan rakyat. Peningkatan jumlah partisipasi pemilih pada Pemilu Serentak 2019 menjadi pertanda bahwa dukungan rakyat terhadap demokrasi dan institusi penyelenggara mengalami peningkatan, meskipun pada bagian lain terjadi krisis legitimasi terhadap penyelenggara negara. Sejalan dengan itu, Pippa Norris menyebut bahwa dukungan publik atas sistem politik yang demokratis tidak terkikis secara konsisten di berbagai negara di seluruh dunia.... meskipun di banyak negara sekarang ini, kepuasan terhadap kinerja demokrasi menyimpang dari aspirasi publik. ${ }^{23}$ Antara tingkat partisipasi yang tinggi pada Pemilu Serentak 2019 dengan arah demokratisasi bangsa tidak sejalan atau deficit demokrasi, menunjukkan makin tingginya tingkat pengetahuan politik warga, tumbuhnya komunitas kritis dan membaiknya pemahaman bahwa demokrasi menjadi pintu untuk menghasilkan kepemimpinan politik yang ideal, kepemimpinan yang mencerminkan aspirasi dan kehendak umum warga negara.

Merosotnya dukungan publik terhadap elite berkuasa sebagai konsekuensi makin meningkatnya kesadaran kritis warga dalam politik, bahwa demokrasi harus terus dirawat dengan satu kesadaran dan sikap kritis terhadap proses politik, tetapi pada saat yang sama melakukan koreksi dan kritis terhadap kinerja lembaga-lembaga politik. Fenomena penangkapan elite politik oleh Komisi Pemberantasan Korupsi (KPK) sebagai fakta bahwa elite berkuasa menyalahgunakan kekuasaannya untuk kepentingan pribadi dan kelompok. Dalam Pemilu Serentak 2019, warga/rakyat menentukan pilihan politiknya atas berbagai pertimbangan dan karakteristik sosial ekonomi dan wilayah serta faktor identitas ikut menentukan pilihan-pilihan politik warga. ${ }^{24}$

23 Saiful Mujani, R. William Liddle, dan Kuskridho Ambardi, Kaum Demokrat Kritis: Analisis Perilaku Pemilih Indonesia dan Demokratisasi (Jakarta: KPG, 2019), h. 4-5.

${ }^{24}$ Gagalnya sejumlah caleg pada Pemilu Serentak 2019 disebabkan oleh factor identitas, geografis, ekonomi dan pertimbangan social. Misalnya, kegagalan elite berpengaruh di masa lalu dan pemimpin pemerintah dalam kontestasi Pemilu 2019 banyak dipengaruhi oleh faktor identitas dan geografis, demikian juga elite yang lain. 
Pergeseran kesetiaan pemilih dalam Pemilu berpengaruh signifikan bagi pergeseran kekuasaan pada level elite, munculnya elite baru dengan "partai baru" hasil Pemilu 2019 dapat dibaca dengan melihat pergeseran perilaku dan kesetiaan pemilih yang berubah drastis. Sebagai contoh, pada Pilkada 2013, Syahrul Yasin Limpo berpasangan dengan Agus Arifin Nu'mang memperoleh kemenangan besar dengan mengungguli pasangan calon lainnya, suatu dukungan publik yang sangat tinggi melampaui angka 50-an persen lebih, namun enam tahun kemudian pasca Pilkada 2013 tersebut, ketika Syahrul Yasin Limpo dan Agus Arifin Nu'mang maju sebagai calon legislatif pada daerah Pemilihan yang berbeda, keduanya gagal terpilih sebagai anggota legislatif. Fenomena ini menunjukkan bahwa pergeseran perilaku pemilih dalam Pemilu Serentak 2019 terjadi sangat dinamis, elite yang cukup berpengaruh, pernah menjadi pimpinan daerah selama 15 tahun gagal memperoleh dukungan rakyat melalui Pemilu 2019.

Fenomena kegagalan elite-elite berpengaruh pada Pemilu 2019 mengonfirmasi bahwa popularitas tidak cukup untuk memperoleh dukungan publik, ketika rakyat makin meningkat kesadaran politiknya, maka jaringan kuasa dan popularitas yang dimiliki oleh elite-elite berkuasa tidak memberi garansi yang pasti bagi keterpilihan mereka pada proses Pemilu. Selama ini muncul anggapan bahwa rakyat Indonesia secara keseluruhan dianggap sebagai warga negara yang mudah melupakan janji para elite politik, misalnya janji-janji elite politik yang berkuasa pada setiap momen Pemilu tidak banyak terealisasi, janji politik tidak lagi dipandang hanya sebagai "basa-basi" elite ketika kampanye, tetapi masyarakat menuntut realisasi janji-janji itu. Rakyat sudah mulai melek politik dan menentukan pilihan dengan berbagai pertimbangan, termasuk pertimbangan rasional.

Gagalnya sejumlah elite lama memperebutkan kembali kursi wakil rakyat, baik untuk DPR RI, DPRD Provinsi maupun untuk DPRD kabupaten/kota di Sulawesi Selatan menunjukkan adanya perubahan pada struktur sosial masyarakat, termasuk potensi distrust terhadap elite berkuasa dan rakyat menghendaki adanya perubahan formasi dan konfigurasi elite pasca Pemilu Serentak 2019. Berdasarkan hasil rekapitulasi KPU Kabupaten/Kota dan provinsi di Sulawesi Selatan mengonfirmasi bahwa elite terpilih tidak lagi didominasi oleh partai tertentu, juga sejumlah elite berkuasa mengalami kegagalan mempertahankan kembali kursi wakil rakyat yang 
selama beberapa periode menjadi "langganan" sebagai anggota legislatif. Pada tingkat DPR RI yang mewakili Sulawesi Selatan sebanyak 24 orang, antara incumbent dengan wajah baru hampir seimbang. ${ }^{25}$ Sejumlah nama terkenal yang maju sebagai caleg gagal terpilih, sebut misalnya mantan Gubernur Sulawesi Selatan dua periode Syahrul Yasin Limpo, mantan Wakil Gubernur Sulawesi Selatan dua periode Agus Arifin Nu'mang, anggota DPR RI yang cukup terkenal karena sering tampil di televisi nasional Akbar Faisal, Bahrum Daido dari Partai Demokrat, Muhtar Tompo dan beberapa nama yang cukup berpengaruh lainnya gagal meraih kursi DPR RI.

Fenomena yang jauh lebih menarik adalah pergeseran dan pertukaran elite pada level legislatif provinsi, sejumlah elite lama gagal terpilih kembali dan elite-elite baru justru memperoleh dukungan yang signifikan pada Pemilu 2019. Fenomena kebangkitan elite milenial dalam politik Sulawesi Selatan menjadi penanda bahwa perubahan sosial yang berlangsung secara massif berhasil membentuk aliansi baru dalam politik lokal. Fenomena Sulawesi Selatan menjadi fenomena umum di sejumlah wilayah, elite-elite baru dengan koneksi politik dan penguasa dan jejaring sosial sebagai satu modal utama yang memberi ruang bagi artikulasi politiknya.

Pertukaran elite dan pergeseran kekuasaan merupakan hasil dari kombinasi antara meningkatnya perilaku kritis pemilih pada satu sisi serta tumbuhnya identitas baru dalam politik menjadi rangkaian yang membentuk pola penyebaran dukungan politik warga. Memudarnya dominasi Partai Golkar dan meratanya dukungan politik warga ke sembilan partai besar menjadi satu fenomena yang sangat menarik dalam politik lokal Sulawesi Selatan. Melalui tabel di bawah ini, tergambar dengan dengan baik proliferasi dukungan politik warga dan peta kekuatan politik di Sulawesi Selatan.

25 Calon anggota legislatif DPR RI Sulawesi Selatan yang terdiri dari tiga daerah pemilihan; untuk Dapil 1: Azikin Solthan, Muh. Rapsel Ali, Hamka B. Kady, Ashabul Kahfi, M. Amir Uskara, Aliyah Mustika Ilham, Ridwan Andi Mittiri, Haruna; Dapil 2: Andi Rio Idris Padjalangi, Andi Iwan Darmawan Aras, Hasnah Syam, Supriansa, Andi Yuliani Paris, Samsu Niang, Muh. Aras, Andi Akmal Pasluddin, Andi Muawiyah Ramli; Dapil 3: Rusdi Masse Mappasessu, Muh. Fauzi, La Tinro La Tunru, Muh. Dhevi Bijak, Mitra Fakhruddin, Sarce Bandaso Tandiasil dan Eva Stevany Rataba. Berdasarkan daftar nama caleg terpilih, wajah baru - meski bukan orang baru dalam politik lebih dari 12 orang. 
Tabel:

Konfigurasi Elite Politik dan Perolehan Kursi DPRD Provinsi Sulawesi Selatan Hasil Pemilu Serentak 2019

\begin{tabular}{|c|c|c|c|c|}
\hline No. & Partai Politi & $\begin{array}{c}\text { Perolehan } \\
\text { Kursi }\end{array}$ & Nama Caleg terpilih & Ket. \\
\hline 1 & $\begin{array}{l}\text { Partai Kebangkitan } \\
\text { Bangsa (PKB) }\end{array}$ & 8 & $\begin{array}{l}\text { 1. Fauzi Andi Wowo } \\
\text { 2. Hengky Yasin } \\
\text { 3. Muhammad Sarif } \\
\text { 4. A M Anwar Purnomo } \\
\text { 5. Anwar A Recca } \\
\text { 6. Andi Tenriliweng } \\
\text { 7. Azhar Arsyad } \\
\text { 8. Irwan Hamid }\end{array}$ & $\begin{array}{l}\text { PKB merupakan } \\
\text { partai politik yang } \\
\text { sangat signifikan } \\
\text { peningkatan } \\
\text { perolehan suara dan } \\
\text { kursinya, baik di } \\
\text { tingkat provinsi } \\
\text { maupun } \\
\text { kabupaten/kota }\end{array}$ \\
\hline 2 & Partai Gerindra & 11 & $\begin{array}{l}\text { 1. Edward Wijaya Horas } \\
\text { 2. Misriani Ilyas } \\
\text { 3. Darmawangsa Muin } \\
\text { 4. Vonny Ameliani Suardi } \\
\text { 5. A Muchtar Mappatoba } \\
\text { 6. Andi Nirawati } \\
\text { 7. A Mangunsidi } \\
\text { 8. Henny Latif } \\
\text { 9. Rusdin Tabi } \\
\text { 10. Firmina Tallulembang } \\
\text { 11. Marjono }\end{array}$ & $\begin{array}{l}\text { Partai Gerindra juga } \\
\text { merupakan partai } \\
\text { yang mengalami } \\
\text { peningkatan } \\
\text { perolehan suara dan } \\
\text { kursinya. }\end{array}$ \\
\hline 3 & $\begin{array}{l}\text { Partai Demokrasi } \\
\text { Indonesia Perjuangan } \\
\text { (PDIP) }\end{array}$ & 8 & $\begin{array}{l}\text { 1. Rudy Pieter Gony } \\
\text { 2. Novianus YL Patanduk } \\
\text { 3. Rahmat Muhayyang } \\
\text { 4. A Putra Batara Lantara } \\
\text { 5. Andi Ansyari Mangkona } \\
\text { 6. Kartini Lolo } \\
\text { 7. Dan Pongtasik } \\
\text { 8. Esra Lamban }\end{array}$ & $\begin{array}{l}\text { PDI Perjuangan } \\
\text { mengalami } \\
\text { peningkatan } \\
\text { perolehan suara dan } \\
\text { kursinya, dari } 5 \\
\text { kursi menjadi } 8 .\end{array}$ \\
\hline 4 & Partai Golkar & 13 & $\begin{array}{l}\text { 1. Andi Debbie Purnama } \\
\text { 2. Rahman Pina } \\
\text { 3. Fahruddin Rangga } \\
\text { 4. Ince Langke } \\
\text { 5. A Ayu Andira } \\
\text { 6. Sofyan Syam } \\
\text { 7. Ina Kartika Sari } \\
\text { 8. A Izman Maulana } \\
\text { Padjalangi } \\
\text { 9. Andi Haerani } \\
\text { 10. Zulkifli Zain }\end{array}$ & $\begin{array}{l}\text { Perolehan suara } \\
\text { Partai Golkar } \\
\text { mengalami } \\
\text { penurunan yang } \\
\text { sangat drastis bila } \\
\text { dibandingkan } \\
\text { dengan Pemilu } \\
\text { 2014, dari } 18 \text { kursi } \\
\text { menjadi } 13 \text { kursi, } \\
\text { kehilangan } 5 \text { kursi. }\end{array}$ \\
\hline
\end{tabular}




\begin{tabular}{|c|c|c|c|c|}
\hline & & & $\begin{array}{l}\text { 11. Jhon Rende Mangontan } \\
\text { 12. Taqwa Muller } \\
\text { 13. Hatta Marakarma }\end{array}$ & \\
\hline 5 & Partai Nasdem & 12 & $\begin{array}{l}\text { 1. A Rachmatika Dewi } \\
\text { 2. Andre Prasetyo Tanta } \\
\text { 3. Rezki Mulfiati Lutfi } \\
\text { 4. Capt. Hariadi } \\
\text { 5. Ady Ansar } \\
\text { 6. Arum Spink } \\
\text { 7. Irwan } \\
\text { 8. Muhammad } \\
\text { 9. Desy Susanty Sutomo } \\
\text { 10. Syahruddin Alrif } \\
\text { 11. Sarwindye Biringkanae } \\
\text { 12. Rakhmat Kasjim }\end{array}$ & $\begin{array}{l}\text { Partai Nasdem } \\
\text { meningkat tajam } \\
\text { perolehan suara dan } \\
\text { kursinya dan kini } \\
\text { menempati posisi } \\
\text { nomor dua. }\end{array}$ \\
\hline 6 & $\begin{array}{l}\text { Partai Keadilan } \\
\text { Sejahtera (PKS) }\end{array}$ & 8 & $\begin{array}{l}\text { 1. Sri Rahmi } \\
\text { 2. Haslinda } \\
\text { 3. Meity Rahmatia } \\
\text { 4. Isnayani } \\
\text { 5. Muzayyin Arif } \\
\text { 6. Ismail } \\
\text { 7. Vera Firdaus } \\
\text { 8. Andi Syarifuddin } \\
\text { Patahuddin }\end{array}$ & $\begin{array}{l}\text { PKS bertambah } \\
\text { satu kursi dari } \\
\text { perolehan tahun } \\
2014 \text {. }\end{array}$ \\
\hline 7 & $\begin{array}{l}\text { Partai Persatuan } \\
\text { Pembangunan (PPP) }\end{array}$ & 6 & $\begin{array}{l}\text { 1. Imam Fauzan AU } \\
\text { 2. Rismayanti } \\
\text { 3. A Sugiarti Mangun } \\
\text { Karim } \\
\text { 4. A Nurhidayati } \\
\text { Zainuddin } \\
\text { 5. Saharuddin } \\
\text { 6. Jabbar Idris }\end{array}$ & $\begin{array}{l}\text { PPP juga stagnan } \\
\text { perolehan kursinya, } \\
\text { bahkan turun dari } \\
\text { Pemilu } 2014 .\end{array}$ \\
\hline 8 & $\begin{array}{l}\text { Partai Amanat } \\
\text { Nasional (PAN) }\end{array}$ & 7 & $\begin{array}{l}\text { 1. Usman Lonta } \\
\text { 2. Syamsuddin Karlos } \\
\text { 3. Edy Manaf } \\
\text { 4. AM Irfan AB } \\
\text { 5. Andi Irwandi Natsir } \\
\text { 6. Arifin Bando } \\
\text { 7. Husmaruddin }\end{array}$ & $\begin{array}{l}\text { PAN mengalami } \\
\text { penurunan } \\
\text { perolehan kursinya } \\
\text { dihampir seluruh } \\
\text { Sulawesi Selatan. }\end{array}$ \\
\hline 9 & Partai Demokrat & 10 & $\begin{array}{l}\text { 1. Andi Januar Jaury } \\
\text { 2. Haidar Madjid } \\
\text { 3. Rismawati Kadir } \\
\text { Nyampa } \\
\text { 4. Mulyadi Mustamnu } \\
\text { 5. Ni'matullah } \\
\text { 6. Syahrir }\end{array}$ & $\begin{array}{l}\text { Partai Demokrat } \\
\text { juga menurun } \\
\text { perolehan suaranya } \\
\text { bila dibandingkan } \\
\text { tahun } 2014 .\end{array}$ \\
\hline
\end{tabular}




\begin{tabular}{|l|l|c|l|l|}
\hline & & & $\begin{array}{l}\text { 7. Selle KS Dalle } \\
\text { 8. Andi Azizah Irma } \\
\text { Wahyudiyati } \\
\text { 9. Jufri Sambara } \\
\text { 10. Fadriaty A.S. }\end{array}$ & \\
\hline 10 & Partai Perindo & 1 & 1. Muh. Anzar Zainal Bate & $\begin{array}{l}\text { Partai baru } \\
\text { memperoleh satu } \\
\text { kursi. }\end{array}$ \\
\hline 11 & Partai Hanura & 1 & 1. Wahyuddin M. Nur & $\begin{array}{l}\text { Hanura mengalami } \\
\text { defisit perolehan } \\
\text { suara yang } \\
\text { signifikan. }\end{array}$ \\
\hline & Jumlah & $\mathbf{8 5}$ & & \\
\hline
\end{tabular}

Sumber: Data hasil Rekapitulasi Komisi Pemilihan Umum (KPU) Provinsi Sulawesi Selatan pada tanggal 8-18 Mei 2019 di Hotel Harper Makassar

Berdasarkan data di atas bahwa komposisi perwakilan politik pada Lembaga Legislatif Provinsi Sulawesi Selatan periode 2019-2024 menunjukkan adanya peningkatan jumlah keterwakilan perempuan. Berdasarkan perolehan suara dan penetapan perolehan kursi anggota parlemen, terdapat sembilan partai politik yang memperoleh dukungan suara signifikan, sejalan dengan perolehan suara partai pada level nasional, sementara terdapat dua partai yang hanya menempatkan masing-masing satu orang wakil yakni Partai Hanura dan Perindo. Partai Hanura merupakan partai politik lama yang secara mengejutkan perolehan suaranya merosot drastis, dari enam kursi merosot menjadi satu kursi, sementara Perindo merupakan partai baru dan berhasil menempatkan satu wakil pada DPRD Provinsi. ${ }^{26}$

Perolehan suara Hanura yang merosot merupakan fenomena umum, sejumlah partai besar mengalami penurunan perolehan suara, sementara pada beberapa partai lainnya terjadi hal yang sebaliknya, PKB yang pada Pemilu 2014 hanya memperoleh 3 kursi, hasil Pemilu 2019 meningkat tajam menjadi 8 kursi, sementara Partai Nasdem yang semula hanya memperoleh 7 kursi, hasil Pemilu 2019 meningkat menjadi 12 kursi, PDI Perjuangan yang pada Pemilu 2014 hanya memperoleh 5 kursi, hasil Pemilu 2019 meningkat menjadi 8 kursi, PKS pada Pemilu 2014 hanya memperoleh 6 kursi, hasil

${ }^{26}$ KPU Provinsi Sulawesi Selatan, Data Perolehan Suara dan Kursi Partai Politik Pemilu 2014 dan Pemilu 2019. 
Pemilu 2019 meningkat menjadi 8 kursi dan berhasil atas unsur pimpinan DPRD, sementara partai yang menurun perolehan kursinya yakni Partai Golkar menurun dari 18 kursi hasil Pemilu 2014 menjadi 13 kursi hasil Pemilu 2019, PAN menurun dari 9 kursi pada Pemilu 2014 menjadi 7 kursi hasil Pemilu 2019, PPP menurun dari 7 kursi menjadi 6 kursi hasil Pemilu 2019, Partai Demokrat juga menurun dari 11 kursi menjadi 10 kursi hasil Pemilu 2019.

Pertukaran elite dan pergeseran kekuasaan pasca Pemilu 2019 memiliki makna bahwa elite berkuasa tidak hanya sekedar menjalankan kekuasaannya, tetapi harus menunjukkan kinerja dan tidak demikian dengan drastis tergambar dengan jelas bahwa konfigurasi anggota DPRD Provinsi Sulawesi Selatan periode 2019-2024 terdistribusi ke 9 partai besar yang lolos ambang batas minimal 4 persen, hanya ada dua partai yang gagal lolos ambang batas minimal yang bisa menempatkan anggotanya pada DPRD Provinsi Sulawesi Selatan.

\section{Penutup}

Pergeseran elite politik pasca Pemilu Serentak 2019 merupakan suatu keniscayaan, mengingat peran dan artikulasi politik masing-masing elite sebelum dan menjelang pemungutan suara menentukan hasilnya. Beberapa faktor yang ikut menentukan elite terpilih dalam Pemilu; pertama, citra kandidat atau elite mempunyai pengaruh dalam proses keterpilihannya, pertarungan politik bukan lagi partai, melainkan pertarungan antar calon bahkan di internal partai pun pertarungan itu cukup kuat. Dalam hal ini, keterpilihan elite sepenuhnya merupakan hasil kerjanya, kampanye politik yang menawarkan agenda-agenda perubahan dan program yang akan dilakukan sang calon memiliki nilai tersendiri dalam proses pemilihan, sang calon yang biasa dengan masyarakat bawah dan membangun citra positif dengan proses pendekatan kepada komunitas dan basis merupakan model yang lazim digunakan calon. Kedua, dukungan modal politik sangat menentukan keterpilihan calon, sejumlah elite terpilih memiliki koneksi dan jaringan dengan elite berkuasa di daerah, kedekatan hubungan tersebut digunakan untuk mempengaruhi masyarakat pemilih. Modal politik ikut menggerakkan institusi birokrasi lokal dalam rangka mobilisasi dukungan agar calon terpilih. 
Ketiga, dukungan modal sosial menjadi bagian utama dalam proses pemilihan politik, dukungan warga menjadi modal utama keterpilihan seseorang. Calon yang berhasil membangun jaringan sosial yang efektif dengan berbagai komunitas, kelompok sosial dan masyarakat bawah yang mampu memperoleh dukungan sosial, bukan dukungan yang bersifat transaksional seperti membagikan sembilan bahan pokok (Sembako), membagi uang atau barang tertentu kepada warga agar dapat memilih sang calon, melainkan dukungan murni yang merupakan hasil dialog ide dan gagasan untuk ditransformasikan dalam proses politik. Modal sosial juga dapat dihasilkan dari penguatan basis-basis primordial, itu banyak dilakukan oleh elite politik pada Pemilu 2019.

Keempat, politik patronase dan klientalisme ikut menentukan keterpilihan calon dalam Pemilu. Sejumlah calon terpilih pada lembaga legislatif bukanlah karena ketokohan dan relasi sosial yang telah dirawat dalam waktu yang lama, melainkan hasil dari pola hubungan yang bersifat simbiosis mutualisme. Politik pembagian keuntungan politisi dengan mendistribusikan sesuatu secara individual kepada pemilih, para pekerja atau pegiat kampanye, dalam rangka mendapatkan dukungan politik dari mereka. Patronase merupakan pemberian uang tunai, barang, jasa, dan keuntungan ekonomi lainnya (seperti pekerjaan atau kontrak proyek) yang ditujukan untuk individu (misalnya, amplop berisi uang tunai) dan kepada kelompok/komunitas (misalnya, lapangan sepak bola baru untuk para pemuda kampong, jembatan penghubung antar kampung atau pembangunan jalan baru). Fenomena patronase menjadi lazim dalam politik Indonesia, bahkan dalam sinisme yang tinggi, politik patronase jauh lebih diminati oleh para politisi daripada membangun kesadaran politik warga yang akan memperkuat demokrasi.

Pola mempengaruhi warga dilakukan elite politik dengan cara yang praktis yakni pemberian uang tunai yang seringkali dikenal dengan istilah popular serangan fajar atau cara lain yang sama berupa pemberian uang tunai atau barang yang didistribusikan kepada pemilih yang berasal dari dana pribadi sang calon seperti yang dilaporkan oleh calon dapil 2 Sulawesi Selatan, tetapi pemberian ini juga dilakukan dengan menggunakan dana publik (misalnya proyek-proyek yang dibiayai oleh pemerintah). Cara ini biasa dilakukan oleh elite politik yang sedang berkuasa dan 
berusaha untuk memperoleh dukungan warga agar dapat terpilih kembali melalui pemberian dana proyek kepada warga.

\section{DAFTAR PUSTAKA}

Bottomore, Tom B. "Kelas elite dan Masyarakat" dalam Sartono Kartodirdjo (eds.) Kepemimpinan dalam Dimensi Sosial. Jakarta: LP3ES, 1990.

Consuelo G. Sevilla, et.al. Pengantar Metode Penelitian. Terjemahan Alimuddin Tuwu. Jakarta: UI Press, 1993.

Haramain, A. Malik \& MF. Nurhuda. Mengawal Transisi: Refleksi atas Pemantauan Pemilu '99. Jakarta: JAMPPI-UNDP, 2000.

Hardiman, F. Budi. Kritik Ideologi: Pertautang Pengetahuan dan Kepentingan. Yogyakarta, Kanisius, 1993.

Huda, Ni'matul \& M. Imam Nasef. Penataan Demokrasi \& Pemilu di Indonesia Pasca Reformasi. Jakarta: Fajar Interpratama Mandiri, 2017.

Huntington, Samuel P. \& Joan Nelson. No Easy Choice Political Partisipation in Developing Countri. Terjermahan. Jakarta: Rineka Cipta, 1994.

Isjwara, F. Pengantar Ilmu Politik. Jakarta : Bina Cipta, 1992.

Jarry, David \& Julia Jarry. Collin Dictionary of Sociologi. Glasgow :Harper Collins Publishers, 1991.

Johnson, Doyle P. Teori Sosiologi Klasik \& Modern, Jilid II. Jakarta: Gramedia Pustaka Utama, 1994.

Jurdi, Syarifuddin. Elite Muhammadiyah dan Kekuasaan Politik. Yogyakarta: Gadjah Mada University Press, 2004.

Keller, Suzanne. Penguasa dan Kelompok Elit: Peranan Elit dalam Masyarakat Modern. Terjemahan Zahara D Noer. Jakarta: Rajawali Press, 1995.

Kusuma, Mulyana W. "Pelaksanaan Pemilihan Umum Tahun 1999," dalam Juri Ardiantoro (ed.), Transisi Demokrasi: Evaluasi Kritis Penyelenggaraan Pemilu 1999. Jakarta: KIPP Jakarta, 1999.

Mallarangeng, Andi A. "Peraturan Perundang-Undangan Pemilu 1999 dan Agenda Perubahan", dalam Juri Ardiantoro (ed.). Transisi Demokrasi: Evaluasi Kritis Penyelenggaraan Pemilu 1999. Jakarta: KIPP Jakarta, 1999. 
Mujani, Saiful, R. William Liddle \& Kuskridho Ambardi. Kaum Demokrat Kritis: Analisis Perilaku Pemilih Indonesia dan Demokratisasi. Jakarta: KPG, 2019.

Putnam, Robert D. "Studi Perbandingan Elit Politik" dalam Mohtar Mas'oed dan Colin Mac Andrews. Perbandingan Sistem Politik,Cet.XV. Yogyakarta: Gadjah Mada Universty Press, 2000.

Sunarlan. "Gerakan Reformasi Politik". Tesis. Yogyakarta: Program Politik Fisipol UGM, 2000. 